\title{
Medical negligence- Meaning and Scope in India
}

\author{
Kumar L, Bastia BK \\ 'Department of Forensic Medicine \& Toxicology, S B K S Medical Institute \& R C, Gujarat, India
}

\section{ABSTRACT}

It is a principle recognized by our as well as by other legal systems that ignorance of the law is no excuse for violating it. The rule is also expressed in the form of a legal presumption that everyone knows the law. It is the duty of every man to know that part of it which concerns him. A doctor, in particular, is conclusively presumed to know the law, and is dealt with as if he did know it, because in general he can and ought to know it. In the matter of professional liability, the medical profession differs from other occupations for the reason that the former operates in spheres where success cannot be achieved in every case and very often success or failure depends upon factors beyond a medical man's control. Due to the increasing awareness of the rights of a patient in present day society, a medical man has become more vulnerable to being sued by a litigation suit of any kind, civil or criminal. The basis of a medical negligence suit is still alien to the majority of the practicing doctors in our country. Hence, the present article aims at discussing the various aspects of negligence, like the meaning and types of negligence, and the concept of duty of care, degree of care, and standard of care, as considered by the law.

Keywords: degree of care, duty of care, medical negligence, standard of care

\section{INTRODUCTION}

The courts have consistently recognized the hazards associated with the medical practice. The Indian law protects the doctors from criminal liability through sections 88 to 92 of Indian Penal Code (IPC), because the law presumes that a doctor always acts in good faith for the well being of his patient. However, the concept of good faith assumes a complicated role in a medical malpractice suit. The term "Good Faith" is explained in Section 52 of the IPC as "Nothing is said to be done or believed in 'good faith' which is done or believed without due care and attention". ${ }^{1}$

In a judgment relating to medical malpractice, the Supreme Court of India reverberated its feeling holding that "The medical practitioner must bring to his task a reasonable degree of skill and knowledge and must exercise a reasonable degree of care. Neither the very highest nor a very low degree of care and competence judged in the light of the particular circumstances of each case is what the law requires. But where you get a situation which involves the use of special skill or competence, then the test is the standard of the ordinary skill a man exercising and professing to have that special skill. A man need not possess the highest expert skill; it is well established law that it is sufficient if he exercises the ordinary skill of an ordinary competent man exercising that particular art". ${ }^{2}$

However, if a medical man grossly fails below the standard which is expected from him in treating a

\author{
Correspondence: \\ Dr. Lavlesh Kumar \\ Department of Forensic Medicine \& Toxicology S B K S \\ Medical Institute \& R C Piparia, Waghodia, Vadodara, \\ Gujarat, India \\ Phone: $91-9737022050$ \\ E-mail: lavleshkumar@hotmail.com
}


patient, then he becomes criminally liable. The last few decades have seen an increasing upsurge in the number of criminal malpractice suits against the doctors throughout the country. Therefore, keeping in view of the above, in a remarkable judgment, the Supreme Court of India held that a doctor will be held liable for criminal prosecution only for "gross negligence" or if he did not possess the required skill, which he ought to possess in the medical profession. ${ }^{3}$ Writing the judgments, the CJI said "The negligence attributed to the doctor must be gross in nature to make him liable for criminal prosecution. To prosecute a medical professional for negligence under criminal law, it must be shown that the accused did something which in the given fact and circumstances no medical professional in his ordinary senses and prudence would have done or failed to do".

Therefore, for a trial, a prima facie evidence must be produced before a court in the form of credible opinion given by another competent doctor relating to the degree of rashness or negligence on the part of a negligent doctor. The burden of proof lies with the patient (with some exceptions), and he has to prove before the court that the damage suffered by him is the direct result of the negligent act of the doctor.

\section{Negligence and law (meaning and definition)}

In Roman law, negligence is signified by the terms "culpa" and "negligentia"; as contrasted with "dolus" or wrongful intention. Care or absence of "negligentia" is "deligentia". The use of the word diligence in this sense is obsolete in modern English, though it is still retained as an archaism of legal diction. ${ }^{4}$

Negligence is culpable (punishable) carelessness conduct which involves an unreasonably great risk of causing harm to another. It is the absence of such care as it was the duty of the defendant to use. It excludes wrongful intention in that no result which is due to carelessness can have also been intended and nothing which was intended can have been due to carelessness. Wrongful intention (mens rea) implies design and purpose while negligence implies that somebody is acting carelessly and without that design.

Medical negligence is an act or omission by a health care provider which deviates from accepted standards of practice in the medical community and which causes injury to the patient. Negligence is defined as the omission to do something which a reasonable man guided upon those considerations which ordinarily regulate the conduct of human affairs, would do, or doing something which a prudent and reasonable man would not do. ${ }^{5}$

There are three forms of negligence, namely,

1. That in which the consequences are foreseen and wrongfully intended.
2. That in which they are not intended but are foreseen and should have been avoided.

3. That in which they are neither foreseen nor intended, but ought to have been foreseen and avoided.

The first clause, of course, is a crime. But a medical practitioner must always be careful enough to avoid the second clause because defense available is not always sufficient. Regarding the third clause, the law presumes that a doctor should be careful enough to avoid the unforeseen dangers because of his specialized training.

\section{Elements of negligence}

A plaintiff, i.e., the patient or a legally-designated party acting on behalf of the patient, must establish all four of the following elements, for a successful medical malpractice claim.

A duty of care owed - a legal duty exists whenever a hospital or health care provider undertakes care or treatment of a patient.

A duty was breached or failed and the provider failed to conform to the relevant standard of care. The standard of care is proved by expert testimony or by obvious errors (the doctrine of "res ipsa loquitor" or "the thing speaks for itself"). An exception to this rule requiring expert testimony is included in the concept of abandonment, an allegation where a physician stopped treating an established patient without a substitute equally skilled and trained or without providing adequate notice for the patient to find alternative care without risk.

The breach caused an injury. The breach of duty was the proximate cause of the injury which was reasonably foreseeable.

Damage. Without damage (loss which may be pecuniary or emotional), there is no basis for a claim, regardless of whether the medical provider was negligent or not.

\section{Liability for negligence}

According to this theory, a man is responsible irrespective of the existence of either wrongful intent or negligence. They are the exception to the general requirement of fault. In the civil as opposed to the criminal law, strict liability is the rule rather than the exception. In the criminal law, liability is usually based on the presence of mens rea. It means no man shall be punished unless he knew that he was doing wrong, or at least, a reasonable person in his position could have avoided the harmful effect by taking reasonable care. But in the civil law, if someone does any harm he has to pay for it, irrespective of whether he did it willfully or negligently or by inevitable accident. In such cases, he has actually done the harm, and therefore he is bound to undo it by paying compensation, for the essential aim of civil proceedings is redress for harm suffered by the plaintiff, not punishment for wrong done by the 
Kumar et al. Medical negligence- Meaning and Scope in India

defendant. The principle is the transfer of loss from the plaintiff to the defendant by enforcing compensation. ${ }^{4}$

\section{Civil and criminal negligence}

The distinction between criminal negligence (crimes) and civil negligence is roughly that the former is a public wrong and the latter is a private wrong. Traditionally, wrongs are divided into two classes, private wrongs and public wrongs. The former are an infringement or privation of the private or civil rights belonging to individuals and thereupon frequently termed as civil injuries; the latter are a breach and violation of public rights and duties which affects the whole community, and are distinguished by the harsher appellation of crimes and misdemeanors. A crime then is an act deemed by the law to be harmful to society in general, even though its immediate victim is an individual. The "gross negligence" in medical practice, as pointed out by the Honorable Supreme Court, is that even though the injures are primarily to a particular victim, its blatant disregard of human life puts it beyond a matter of mere compensation between the accused and the victim's family, and makes the accused liable for a criminal proceeding.

\section{Duty of Care}

Per se, carelessness is not culpable, or a ground of legal liability, expect in those cases in which the law has imposed a duty of carefulness. In civil law, negligence constitutes a majoring of cases. When there is a legal duty not to do a thing on purpose, there is commonly a legal duty to take care not to do it accidentally. In civil law, a duty of care is a legal obligation imposed on an individual requiring that they exercise a reasonable standard of care while performing any act that could foreseeably do harm to others. For an action in negligence, there must be an identified duty of care in law. In medical practice, the law has imposed a duty of care on the doctors for treating patients. Duties which a doctor owes to his patient are clear. They includes a duty of care in deciding whether to undertake the case, in deciding what treatment to give, and in the administration of treatment. A breach of any of these duties gives a right of action for negligence to the patient.

If a patient comes to a hospital and the doctor starts seeing the patient, this duty of care starts, irrespective of whether informed consent has been given or not. The welfare of his patient is total and it is the duty of the doctor not only to treat the disease but to take sufficient precaution so that the patient does not suffer due to the adverse effects of the treatment regimen. Therefore the duty of care for a doctor includes doing all the investigations, interpreting their results, diagnosing the disease promptly and properly, treatment of the disease, and follow-up of the patient till he gets completely cured.

All the above-mentioned duties including the duty of referral are imposed on the treating physician only.
Expert opinion regarding a finding, radiological reports, biochemical reports, chemical analysis of poisons and consultation do not come under the purview of this care. The duty of care on a patient is not imposed on a laboratory although it analyses the body fluids and gives a guide line for treatment. It is the duty of the treating physician to interpret the positive and negative findings, true or false findings, correlate these with the clinical picture and to give the best treatment available. Similarly, the advice of another doctor will be taken like results of a laboratory.

\section{Standard of Care}

The law doesn't insist on any standard of care which would include them within the limit of culpable negligence. But individuals who are considered to be professionals within the society are expected to hold to a higher standard of care than those who are not. It is for the law to draw the line as best it can, so that while prohibiting unreasonable carelessness, it does at the same time demand reasonable care.

In civil laws, the standard of care is the degree of prudence and caution required of an individual who is under a duty of care. A breach of the standard is necessary for a successful action in negligence. In certain professions, the standard of care is determined by the standard that would be exercised by the reasonably prudent professional in that line of work. Such a test, known as the Bolam test, is used to determine whether a doctor is liable for medical malpractice. ${ }^{6}$

The reasonable person standard is a legal fiction that originated in the development of the common law. The reasonable person is a rational, reasonably intelligent individual who is intended to represent a sort of average citizen. The ability of this individual to understand matters is consulted in the process of making decisions of law. The question "how would a reasonable person act under the circumstances" performs a critical role in legal reasoning in areas such as negligence. Thus, the law imposes the duty of care, but the standard is a matter of medical judgment.

\section{Degree of care}

Carelessness may exist in any degree. In this respect it differs from the other forms of mens rea. Intention either exists or it does not; there can be no question of the degree in which it is present. But the degree of carelessness varies directly with the risk to which other persons are exposed by the act in questions.

A person is careless who, without intending evil, nevertheless, exposes others to the danger of it, and the greater the danger, the greater the carelessness. The risk depends on the magnitude of the threatened evil and the probability of it. The greater the evil is and the nearer it is, the greater is the carelessness of the defendant. 
As carelessness varies in degree, it is necessary to know what degree of it is required for culpable negligence and what measure of care the law demands. The law does not demand the highest degree of care of which human nature is capable but that which is reasonable, in view of the magnitude of the risk. The law, therefore, allows every man to expose his actions to a certain degree of risk and with full knowledge.

The greater the danger and the greater its likelihood, the greater is the defendants carelessness in not taking precaution against it. There are degrees of negligence then and these could be taken into account by law for both civil and criminal purposes. In crimes of negligence the law could provide that the greater the negligence the greater the punishment. Ordinary negligence is such failure to use care as would render a person civilly but not criminally liable. Criminal negligence is a greater failure and a greater falling below the standard of care and renders a man guilty criminally. For example, if a new-born child is left to die from want of medical attention or nursing, it may be that, its death is due to negligence only, but it is more probable that it is due to wrongful purpose and malice aforethought. Gross negligence is a yet greater fall below the standard and such a wholly unreasonable failure to take care as to make the defendant not only liable for the offence but also, in the event of his conduct resulting in another person's death, of culpable homicide.

\section{Negligence under the Indian penal code}

The general condition of the penal liability is indicated by the Latin maxim - Actus non facit reum, nisi mens sit rea - the act alone does not amount to guilt; it must be accompanied by a guilty mind. Thus two conditions need to be fulfilled before penal responsibility can be rightly imposed. To attribute mens rea to a wrongful act, it is necessary that the act be done either willfully or recklessly. Where the act is willful, mens rea is obvious.

The Indian law holds a doctor criminally liable for his negligent act under section 304 - A of IPC which states that: "Whoever causes death of any person by doing any rash or negligent act not amounting to culpable homicide, shall be punished with imprisonment of either description for a term which may extend to two years, or with fine, or with both". ${ }^{1}$ A rash and negligent act is one where the person is responsible for the consequences foreseen as the certain or highly probable outcome of his act. The liability under this

\section{REFERENCES}

1. The Indian Penal Code, 1860. Bare Act. Allahabad; Law Publishers India Pvt. Ltd: 1998.

2. Mathiharan K, Patnaik AK. Medical Negligence and Consumer Protection Act. In: Modi's Medical Jurisprudence and Toxicology. 23rd edition. New Delhi; Butterworths: 2005. P. 149-200. section is created on the assumption of foreseeability of consequences which could result from a wrongful act. Thus if a medical practitioner does an act which he did not intend or even foresee but which a reasonable medical practitioner would have foreseen under similar circumstances as likely to cause death, he would be held guilty of the wrongful act.

Criminal rashness means hazarding a dangerous or wanton act with the knowledge that it is so, and that it may cause injury but without intention to cause injury or knowledge that it will probably be caused. The criminality lies in running the risk of doing such an act with recklessness or indifference as to the consequence. For example, a medical practitioner conducts a termination of a 24-week pregnancy but does so without adequate training or with unsterilized instruments. Here the medical practitioner has not exercised the caution incumbent upon him to undertake termination only after adequate training in the procedure and only with sterilized instruments in an adequately equipped set-up.

It is important for a medical practitioner to remember that there can be no civil action for negligence if the negligent act or omission has not been attended by an injury to any person; but bare negligence involving the risk of injury is punishable criminally. For example, a patient is operated upon in an operation theater without oxygen being available. The medical practitioner would be liable under criminal law even though oxygen may not have been needed by the patient. The mere act of exposing the patient to the risk of personal safety or life is enough to bring criminal negligence into play as per section 336 of IPC.

\section{CONCLUSIONS}

Traditionally, courts have been very considerate to medical practice while dealing with professional negligence. However, a clinician has certain specific duties towards his patient. If he or she commits an act which other clinicians of his or her status, standard and competence would not commit or the clinician omits to do something which other clinicians would certainly do, the clinician has performed a negligent act. Practicing with due care, diligence and adopting accepted standard of practice and respecting autonomy of the patient is what is expected from a medical man. In addition, a medical practitioner must act according to the copy of the declaration of the Code of Medical Ethics provided by Indian Medical Council at the time of registration.

3. Mudur G. Indian Supreme Court ruling makes arrest ofdoctors harder. BMJ. 2005 Aug 20;331(7514):422

4. Fitzgerald PJ. Salmond on Jurisprudence. 14th Ed. London; Sweet \& Maxwell: 1966.

5. Denning Lord MR. The Discipline of Law. New Delhi; Aditya Books Private Limited: 1993.

6. Gupta RL. Consent to treatment. In: The Medico legal Aspects of Surgery. 1st Ed. New Delhi; Jaypee Brothers: 1999. P. 16-30. 